\title{
禹 \\ Repairing The World Through Law: \\ A Reflection On Robert Cover's \\ Social Activism
}

\author{
Stephen Wizner
}

To live in a legal world requires that one know not only the precepts, but also their connections to possible and plausible states of affairs. ${ }^{1}$

Law is the projection of an imagined future upon reality. ${ }^{2}$

\section{Introduction: Institutional Change and Character Education}

During the 1985-86 academic year, shortly before his untimely death that summer, Robert Cover drafted and circulated two memoranda to colleagues - "Proposal for a National Law Student Conference for Social Change" and "Proposal for a Post-Graduate Internship Program." ${ }^{3}$ These were among the last of Cover's many "unpublished manuscripts" - a sizable body of lecture notes, correspondence, and memoranda to faculty (and often to students as well).

These two manuscripts contain Cover's final words about the social purposes of law. His first (in writing) probably were those that he wrote two decades earlier in his application for admission to the Columbia Law School

Scholarship, however, is not my major concern. I am far more interested in the uses to which knowledge can be put than in the pursuit of knowledge itself.... For the past several years my two major interests have been institutional change and character education. I view these two areas as prerequisites for the type of societal change that I would like to see brought about in the future. ${ }^{4}$

In his law school application Cover wrote about the year he had spent 
in Southwest Georgia working for social change. He was engaged in voter registration with the Student Nonviolent Coordinating Committee, and served as a local liaison with the National Sharecropper's Fund, helping to organize the first conference of Black small farmers and sharecroppers with state and federal government officials.

In that same application essay Cover wrote about a project he had initiated and administered while a counselor at a Jewish summer camp. He had brought 80 campers to an impoverished inner city community to clean, paint and refurbish a local community center in order to introduce them to, and teach them something about, the nature and extent of poverty in urban areas.

Social justice issues such as these motivated and informed Cover's life in the law to the very end. Speaking out at political demonstrations, conducting teach-ins with students seeking divestment of university funds from apartheid South Africa, walking picket lines in support of workers seeking better wages and working conditions, joining with students seeking to help the homeless, were all part of Cover's law teaching and practice. ${ }^{5}$ In his "Proposal for a National Law Student Conference for Social Change" Cover's belief that law is a call to public service, social change, and community emerges vividly:

Law students and young lawyers who are committed to careers in public service are an important national resource. In almost every law school in the land there are a few students who have embarked upon the study of law because they believe the profession to be an important opportunity for social change, an important avenue in the struggle for social justice ... [O]nly a few are committed to the less secure, less lucrative and more frustrating careers in the public sector. Indeed, as law students are educated not only in law but in the realities of professional life, as they come to understand both what they must give and what they must give up for such a career, fewer and fewer create lives in the public service.

...[W] hen, as now, public life is dominated by an ideology of gain and privatism, whatever support there is for 
such choices of a career in public service is generated almost entirely by the students, their families and professional mentors...

It is also the case that careers in public service work seem more exciting and worthwhile when there is a sense of movement - of common effort and common commitment. That sense was present when OEO Legal Services Organizations were first formed in the late 1960's and early 1970's. It was present in the legal work of the civil rights movement. It is not widespread today. ${ }^{6}$

The proposal goes on to call for a national conference of committed law students, from a variety of schools, that would meet for several days and would serve four related purposes:

First, it would be an opportunity to break the isolation. Students from around the country with common concerns would get to know one another and would realize our national scope of problems and professional opportunity. Second, students would interact with lawyers, legal academics, and other professionals who might provide both practical guidance and role models for the variety of possible public service careers; third, the conference would be a forum for thinking about reform or change of legal education; fourth, the conference would provide students with a jump-off or starting place for the formulation of programmatic politics of legal change. ${ }^{7}$

Cover's belief that the law schools ought to provide mechanisms that facilitate students' entry into public interest practice is summarized in his last unpublished manuscript, "Proposal for a Post-Graduate Internship Program," which he characterized as "a serious non-profit sector alternative to the large law firm for the training of young lawyers."

The proposal opens with the following words:

The vast majority of graduates of the elite law schools of this nation seek and find employment in the large corporate law firms of our major cities. Most of the lawyers 
serve honorably among the leaders of the profession. But they serve predominantly in a rather narrow band of the spectrum of legal jobs. The jobs they do fill are critical ones in the transactions that characterize a mature capitalist, industrial, economy both internally within the private sector and in that sector's relation to government taxation, regulation, and promotion. As important as these roles in business transactions may be, the vast majority of these attorneys seldom or never experience the dimensions of lawyering that are the bed-rock, selfjustifying core of the profession. That core in law is the needs of the individual client whose life, liberty, or private property is at risk through the acts of the state or through the threatening acts of private persons or organizations. When a lawyer represents such a client he does that which is as necessary to our social existence as the physician's role is to our physical well being. ${ }^{8}$

The proposal goes on to describe and advocate a clinical legal internship program for recent law school graduates in which they would rotate through four public interest practice situations: high volume client service; litigation practice (including class actions and test cases) employing social science methods; transaction planning; and public agency assessment and planning. In each rotation the intern would receive close supervision and training from a mentor while enjoying significant responsibility.

Cover intended these four rotations to be a "legal analog of a teaching hospital."

It is characteristic of medical training that all doctors experience - at least for their years of internship and residency - the self-justifying core work of their profession. They experience the world of the very ill and come to sense the critical role they, themselves, play in that world.

The goal of the public interest internship proposal was to enable recent law graduates to experience what Cover believed was the self-justifying core work of their profession, and to sense the critical role they, 
themselves, could play in that world.9

In these, his final unpublished manuscripts, Robert Cover crystallized his thinking about what he had referred to twenty years earlier as his interest in "institutional change and character education." 10 What emerges from these two remarkable documents is a prophetic voice, simultaneously critical and hopeful, calling upon the academic legal community to recognize and act upon its obligation to promote the repair of the world through law.

\section{A Jewish Jurisprudence of the Social Order"}

There was a powerful connection between Robert Cover's legal scholarship and his social activism. Both were motivated and informed by his Judaism - his education, socialization and acculturation as a Jew, and his life-long study of Jewish texts. Cover described himself as having been "graced with a deep and abiding religious background."12

Here is the testimony of Rabbi Joseph Lukinsky, a Professor at the Jewish Theological Seminary, who was Cover's teacher:

In the summer of 1960, I was assistant rabbi and youth program director at Congregation Kehillath Israel, Brookline, Massachusetts. I hired Bob Cover, then sixteen years old, for the summer to help prepare educational programs and materials for the coming year. The summer's work, for which Bob received the magnificent sum of one hundred dollars, took place every afternoon, but the mornings were for study of the Talmud. From 11:00 to 12:00 we would review what he had studied on his own during the previous two hours. Often, I admit, the Talmudic discussion continued through lunch into the afternoon's "work" period.... Bob had some previous Talmudic background, having studied in the high school department of the Boston Hebrew College, but the text, with its Aramaic terminology and condensed and rigorous logic, was not easy. Nevertheless, before the summer was over I had the distinct impression that I was no longer the teacher, but had become his haver (fellow student); in some respects, he had become the teacher! ${ }^{13}$ 
Especially in "Nomos and Narrative," but also in his other published work, Cover's extensive knowledge of and reliance upon Jewish texts are evident. ${ }^{14}$ These texts, and their religious and social meanings, also served as the basis for Cover's social activism.

When I am asked to reflect upon Judaism and human rights... the first thought that comes to mind is that the categories are wrong. I do not mean, of course, that basic ideas of human dignity and worth are not powerfully expressed in the Jewish legal and literary traditions. Rather, I mean that because it is a legal tradition Judaism has its own categories for expressing through law the worth and dignity of each human being.... The principal word in Jewish law, which occupies a place equivalent in evocative force to the American legal system's "rights," is the word "mitzvah" which literally means commandment but has a general meaning closer to "incumbent obligation."15

A motif that runs throughout the Jewish texts in which Cover was immersed is the obligation to engage in socially responsible behavior, in gemilut hasadim - acts of loving kindness - and tikkun olam - repair of the world. A central theme of the Torah, the Prophets and the Writings is "justice," understood not in the Greek sense of harmony, but rather as righteousness and the doing of good deeds. In Hebrew the word for justice (tzedek) and the world for charity (tzedakah) are from the same root.

In Jewish religious texts the people are repeatedly admonished to be kind and generous to the stranger, the widow, the orphan and the poor. Doing justice is an obligation commanded by God. ${ }^{16}$

The idea of commandments (mitzvot) that impose obligations on individuals to pursue justice permeates Jewish thought, engendering what Cover called "a Jewish jurisprudence of the social order." ${ }^{\text {"17 }}$ In Cover's words:

The basic word of Judaism is obligation or mitzvah.... [E]verything was given at Sinai. And, of course, therefore, all is, was, and has been commanded - and we are obligated to this command.... Indeed, to be one who acts out of obligation is the closest thing there is to a Jewish definition of completion as a person within the community. ${ }^{18}$ 
Cover distinguished the Jewish, obligation-based approach from the social contract, rights-based approach to social justice.

...[A]s I scan my own - our own - privileged position in the world social order and the national social order, as I attend the spiritual and material blessings of my life and the rather obvious connection that some of these have with the suffering of others - it seems to me that the rhetoric of obligation speaks more sharply to me than that of rights. Of course, I believe that every child has a right to decent education and shelter, food and medical care; of course, I believe that refugees from political oppression have a right to a haven in a free land; of course, I believe that every person has a right to work in dignity and for a decent wage. I do believe and affirm the social contract that grounds those rights. But more to the point I also believe that I am commanded — that we are obligated - to realize those rights. ${ }^{19}$

\section{Bringing the Messiab Through Law: ${ }^{20}$ Interpretation and Committed Social Bebavior}

In March of 1986, in an address at the University of Georgia, Robert Cover took issue with the claim "that there is an essential unity to the interpretive work of law and literature."

The practice of constitutional interpretation is so inextricably bound up with the real threat or practice of violent deeds that it is - and should be - an essentially different discipline from "interpretation" in literature and the humanities. ${ }^{22}$

In "Violence and the Word" Cover further clarified the distinction he saw between law and literature:

Legal interpretive acts signal and occasion the imposition of violence upon others: A judge articulates her understanding of a text, and as a result, somebody loses his freedom, his property, his children, even his life. 
Interpretations in law also constitute justifications for violence which has already occurred or which is about to occur. When [legal] interpreters have finished their work, they frequently leave behind victims whose lives have been torn apart by these organized, social practices of violence. Neither legal interpretation nor the violence it occasions may be properly understood apart from one another. This much is obvious, though the growing literature that argues for the centrality of interpretive practices in law blithely ignores it. ${ }^{23}$

Interpretations of legal texts have real world consequences beyond uncovering meaning, deepening understanding, enhancing appreciation, stimulating the imagination, and generating conversation. No matter how literary the legal text, no matter how central the act of interpretation to its understanding, it is its application that defines its function. Law "connotes legitimacy in the exercise of coercion and in the organization of authority and privilege." ${ }^{24}$

Cover acknowledged that in his two decades of law teaching he had been "concerned with the convergence of law and literature." 25 So what is one to make of this insistence upon an essential dichotomy between legal and literary interpretive activities?

Milner Ball has observed that Robert Cover "took his theology and his law seriously and together." ${ }^{26}$ It is in the light of this important insight that Cover's attitude towards literary interpretation should be understood. Cover also took literature seriously, but, to the extent that literature played a part in his jurisprudential thinking, it did so by presenting, dramatizing and illuminating through narrative the moral complexities imbedded in and reflected by individual and social behavior.

To paraphrase Milner Ball, Cover took his law and his literature seriously and together. In the opening pages of Justice Accused, ${ }^{27}$ Cover invokes the myth of Antigone's disobedience to Creon and Herman Melville's Billy Budd in introducing his study of antislavery judges who enforced Fugitive Slave Laws. In asking why judges who were themselves abolitionists would order the return of fugitive slaves to bondage, Cover turned to the Melville narrative where Captain Vere and his officers condemn Billy to death, while believing that he is morally innocent. 
Cover offers Antigone's defiance of Creon as the mythic act of civil disobedience by a moral individual invoking "a juster justice," but he invites us to move our critical gaze from Antigone to Creon, from the individual moral actor to the established legal order. Similarly, in his treatment of Billy Budd, Cover shifts our focus from Billy to Captain Vere, from "radical innocence personified" to complicity in an unjust legal system.

Cover's reflection on the moral-formal dilemma that antislavery judges faced, and his effort to understand the moral choices that they made, follow upon his interpretation of literary texts in the opening pages. But his real achievement in the book is not the skillful interpretation of literary and legal texts; it is his bringing both himself and the reader to confront the complexities of moral choice, the necessity of making such choices nonetheless, and the existential import of the choices that are made.

Textual interpretation - whether the texts were legal or literary engaged Cover as a person, at a deep moral, as well as intellectual, level. It was not an academic exercise; it was an obligatory activity.

Cover came from a religious tradition in which textual interpretation is a religious practice, equal in importance to worship and ethical behavior. In "Nomos and Narrative" he cites as a foundation of his legal world the words of Simeon the Just, as set down in the ancient redaction of Jewish law known as the Mishnah:

Upon three things the world stands: upon Torah [study of divine law]; upon the temple worship service; and upon deeds of kindness. ${ }^{28}$

The narrative texts that spoke to Cover provoked and necessitated interpretation. However, the activity of interpretation was not only an engagement with texts, but the creation of connections to real and imagined worlds.

Interpretation, as it relates to law,

is a form of bonded interpretation, bound at once to practical application, to the deeds it implies, and to the ecology of jurisdictional rules, the conditions of effective domination. ${ }^{29}$

In Cover's words, "In law to be an interpreter is to be a force, an actor who creates effects through or in the face of violence." 30

In "Nomos and Narrative" Cover had this to say about the relation- 
ship of interpretation to law in the world:

In an imaginary world in which violence played no part in life, law would indeed grow exclusively from the hermeneutic impulse - the human need to create and interpret texts. Law would develop within small communities of mutually committed individuals who cared about the text, about what each made of the text, and about one another and the common life they shared. Such communities might split over major issues of interpretation, but the bonds of social life and mutual concern would permit some interpretive divergence...

But the jurisgenerative principle by which legal meaning proliferates in all communities never exists in isolation from violence. Interpretation always takes place in the shadow of coercion. ${ }^{31}$

Of course, Cover was perfectly capable of imagining worlds. Cover's view of the law as a "bridge" in the "normative space" connecting our understanding of the world as it is with our projections of alternative worlds that might be ${ }^{32}$ confirms Suzanne Stone's observation that Cover was a messianist. ${ }^{33}$ But the worlds that Cover imagined were not imaginary worlds. And the "bridge" by which he defined law was no mere metaphor, but rather "the committed social behavior which constitutes the way a group of people will attempt to get from here to there." 34

Cover's concept of law was messianic. It transformed the Jewish religious belief in the coming of the Messiah, the Jewish longing for the Messianic Age, into a secular political ideal, a progressive, universalistic vision of human progress leading to a world of equality and social justice, of peace and prosperity.

Messianism is a powerful idea. It offers an explanation for social activism from deep within Jewish tradition. It portrays Jews as growing up in a future-oriented culture, longing for a better world. It moves the messianic idea from the spiritual realm onto the stage of history.

For Cover it was important to "maintain the connection between law and reality." ${ }^{35}$ Therefore, his legal messianism, religiously motivated and radical though it was, emphasized "committed practical behavior" in con- 
trast to "spiritual and psychological realities."36

Law ordinarily requires a cautious discernment among commitments... The readiness to move into a pre-messianic mode of judicature is a readiness to dramatically increase the range of current legal commitment. It is to evince not only dramatic dissatisfaction with the world as it is, but a looming responsibility for drastic change.

\section{Conclusion: Legal Education and Social Activism}

Being a student in a class taught by Bob Cover was a very special experience. He was not a performer; rather, he engaged us through his passion for intellectual inquiry, for justice, and for a better world.... With Bob we explored our commitments to law, to our community, and to a just life. He taught us how the law could serve the project of tikkun olam, the repair of the world, but also how the law often functioned to rigidify the divisions of a world in disrepair. ${ }^{38}$

These words of Robert Cover's student evoke what he wrote in his law school application, where he identified "institutional change and character education... as prerequisites for the type of societal change that I would like to see bought about in the future." ${ }^{39}$

For Cover, legal education, properly understood, had a moral, as well as an intellectual purpose. It was not limited to, or even primarily about, the acquisition of legal knowledge or the development of professional skills, although those were essential.

Law does not consist simply of rules and doctrine, or technical skills, or abstract theory and social policy. Teaching the craft of law - including the art of interpretation - is only one part of the educational mission of law schools. ${ }^{40}$

The student of law may come to identify the normative world with the professional paraphernalia of social control. The rules and principles of justice, the formal institutions of the law, and the conventions of a social order 
are, indeed, important to that world; they are, however, but a small part of the normative universe that ought to claim our attention ${ }^{41}$

Analytical rigor, logical reasoning, the ability to see and draw distinctions, a facility at written and oral expression, all are indispensable skills for lawyers. But equally important are an openness and sensitivity to the raw data of human experience, and a capacity for moral indignation at injustices in the world.

It is all well and good that law students learn to "think like lawyers," to argue positions persuasively irrespective of whether they agree with them. It is another matter entirely if, in the process, they lose, or fail to develop, the capacity to care whether they agree or not, to form a judgment about whether the positions they espouse are right or wrong, fair or unfair, just or unjust. Cover taught that

[c]ritical intelligence is a kind of secondary characteristic that operates to implement commitments, that operates to understand the limits to them, that operates to qualify the complexity of the world so that you know that you're not alone and that there are people with other commitments, that all of that is part of your reality; it's all there. But it really is a secondary characteristic that comes into play from the point of commitment that you know and that you understand." 42

The function of law in challenging injustice and working for social change is an appropriate - indeed, obligatory - concern of legal education. Character education can inspire students of law to committed social behavior; committed social behavior is the bridge from the worldthat-is to the world-that-might-be. 


\section{Epilogue}

Beginning with the 1993-94 academic year recent law school graduates, under the auspices of the Robert M. Cover Public Interest Fellowship Program at Yale, have served as clinical teaching fellows, collaborating with clinic faculty and students in representing indigent clients and working for social change.

For the past nine years law students, law professors, and public interest lawyers from across the country have gathered during the first weekend in March at Boston University's Sargent Camp in Peterborough, New Hampshire, for the annual Robert M. Cover Memorial Public Interest Retreat. In workshops, panel discussions, and informal conversation the students, teachers and lawyers learn from, encourage and inspire one another in their common aspiration to repair the world through law.

1 Robert M. Cover, "The Supreme Court, 1982 Term — Forward: Nomos and Narrative," 97 Harvard Law Review 4, (1983).

2 Robert M. Cover, "Violence and the Word," 95 Yale Law Journal 1601, 1604 (1986).

3 Both documents are on file with the author.

4 Quoted in Barbara A. Black, "Tribute to Robert Cover," 96 Yale Law Journal 1703, 1704 (1987).

5 See Steve Wizner, "Tribute to Robert Cover," 96 Yale Law Journal 1701 (1987); Aviam Soifer, "Preface," Narrative, Violence and the Law: The Essays of Robert Cover, M. Minow, M. Ryan, and A. Sarat, eds. (Ann Arbor: University of Michigan Press, 1992), ix-x.

“...Bob Cover was an active spirit ... he knew where he stood. He stood with justice. He stood with virtue. He stood with Local 34 when it demanded that the University recognize clerical and technical workers as full members of this community. He stood with us, his students, when we took a stance to protest the University's investments in South Africa." Tanina Rostain, "Tribute to Robert Cover," 96 Yale Law Journal 1713, 1716.

6 Robert M. Cover, "Proposal for a Narional Law Student Conference for Social Change," at 1-2.

$7 \quad I d$, at 2.

8 Robert M. Cover, "Proposal for a Post-Graduate Internship Program," at 1.

9 Id, at $1-2$.

10 See note 4, supra.

11 Robert M. Cover, "Obligation: A Jewish Jurisprudence of the Social Order," 5 Journal Law and Religion 65 (1988).

12 Id, at

13 Joseph Lukinsky, "Law in Education: A Reminiscence with Some Footnotes to Robert Cover's Nomos and Narrative," 96 Yale Law Journal 1836 (1987). 
14 See, e.g., Cover, "Nomos and Narrative," supra note 1 at 11-13, 15, 20-24, 41; Id., "Violence and the Word," supra note 2; Id., "Folkmales of Justice," 14 Capital University Law Review 179, 183-197 (1985); Id., "A Jewish Jurisprudence of the Social Order," supra note 11.

15 Cover, "A Jewish Jurisprudence of the Social Order," supra note 11.

16 See, e.g., Exodus 2:20-26; Deuteronomy 16:20; Isaiah 58:2-9; Amos 5:21-24; Micah 6: 6-8; Jeremiah 7:1-7; Psalms 82; Proverbs 21:3 and 31:8-9.

17 Cover, "A Jewish Jurisprudence of the Social Order," supra nore $11 .$.

18 Id., at 66-67.

19 Id, at 73-74.

20 Robert M. Cover, "Bringing the Messiah Through Law: A Case Study," NOMOS XXX: Religion, Morality and the Law, R. Pennock and J. Chapman eds. (New York: New York University Press, 1988); "The Folktales of Justice," 187-195.

21 Robert M. Cover, "The Bonds of Constitutional Interpretation: Of the Word, the Deed, and the Role," 20 Georgia Law Review 815 (1986).

$22 I d$, at 816.

23 Cover, "Violence and the Word," supra note 2.

24 Cover, "The Folktales of Justice," supra note 14 at 180.

25 Cover, "The Bonds of Constitutional Interpretation," supra note 21 at 815.

26 Milner Ball, The Word and the Law (Chicago: University of Chicago Press, 1993), p.3.

27 Robert Cover, Justice Accused: Antislavery and the Judicial Process (New Haven: Yale University Press, 1975), pp.1-7.

28 Quoted in Cover, "Nomos and Narrative," supra note 1 at 11.

29 Cover, "The Bonds of Constitutional Interpretation," supra note 21 at 820-821.

$30 \quad$ Id, at 833.

31 Cover, "Nomos and Narrative," supra note 1 at 40.

32 See, e.g., Cover, "Nomos and Narrative," supra note 1 at 9; "Folktales of Justice," supra note 14 at 181-182.

33 Suzanne Last Stone, "In Pursuit of the Counter-Text: The Turn to the Jewish Legal Model in Contemporary Legal Thought," 106 Harvard Law Review 813, 893 (1993).

34 Cover, "Folktales of Justice," supra note 14 at 181.

35 Id, at 204.

36 Id, at 197.

37 Id., at 196-197.

38 Rostain, supra note 5 at 1713-1714.

39 See note 4, supra.

40 "Education needs to create worlds for students to experience, rather than to reduce such worlds to the learning of abstract concepts or information. "Lukinsky, supra note 13 at 1855.

41 Cover, "Nomos and Narrative," supra note 1 at 85-96.

42 Quoted in Rostain, supra note 30 at 1716. 